NASA/TM-2003-212349

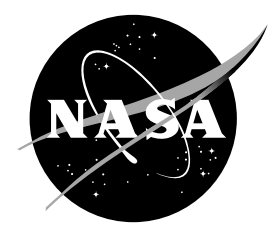

\title{
High Power MPD Nuclear Electric Propulsion (NEP) for Artificial Gravity HOPE Missions to Callisto
}

Melissa L. McGuire, Stanley K. Borowski, and Lee M. Mason

Glenn Research Center, Cleveland, Ohio

James Gilland

Ohio Aerospace Institute, Brook Park, Ohio 
Since its founding, NASA has been dedicated to the advancement of aeronautics and space science. The NASA Scientific and Technical Information (STI) Program Office plays a key part in helping NASA maintain this important role.

The NASA STI Program Office is operated by Langley Research Center, the Lead Center for NASA's scientific and technical information. The NASA STI Program Office provides access to the NASA STI Database, the largest collection of aeronautical and space science STI in the world. The Program Office is also NASA's institutional mechanism for disseminating the results of its research and development activities. These results are published by NASA in the NASA STI Report Series, which includes the following report types:

- $\quad$ TECHNICAL PUBLICATION. Reports of completed research or a major significant phase of research that present the results of NASA programs and include extensive data or theoretical analysis. Includes compilations of significant scientific and technical data and information deemed to be of continuing reference value. NASA's counterpart of peerreviewed formal professional papers but has less stringent limitations on manuscript length and extent of graphic presentations.

- TECHNICAL MEMORANDUM. Scientific and technical findings that are preliminary or of specialized interest, e.g., quick release reports, working papers, and bibliographies that contain minimal annotation. Does not contain extensive analysis.

- CONTRACTOR REPORT. Scientific and technical findings by NASA-sponsored contractors and grantees.
- CONFERENCE PUBLICATION. Collected papers from scientific and technical conferences, symposia, seminars, or other meetings sponsored or cosponsored by NASA.

- SPECIAL PUBLICATION. Scientific, technical, or historical information from NASA programs, projects, and missions, often concerned with subjects having substantial public interest.

- TECHNICAL TRANSLATION. Englishlanguage translations of foreign scientific and technical material pertinent to NASA's mission.

Specialized services that complement the STI Program Office's diverse offerings include creating custom thesauri, building customized databases, organizing and publishing research results ... even providing videos.

For more information about the NASA STI Program Office, see the following:

- Access the NASA STI Program Home Page at http://www.sti.nasa.gov

- E-mail your question via the Internet to help@sti.nasa.gov

- Fax your question to the NASA Access Help Desk at 301-621-0134

- Telephone the NASA Access Help Desk at 301-621-0390

- Write to:

NASA Access Help Desk

NASA Center for AeroSpace Information 7121 Standard Drive

Hanover, MD 21076 
NASA/TM-2003-212349

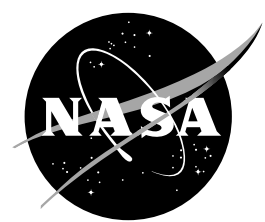

\section{High Power MPD Nuclear Electric Propulsion (NEP) for Artificial Gravity HOPE Missions to Callisto}

Melissa L. McGuire, Stanley K. Borowski, and Lee M. Mason

Glenn Research Center, Cleveland, Ohio

James Gilland

Ohio Aerospace Institute, Brook Park, Ohio

Prepared for the

Space Technology and Applications International Forum (STAIF-2003) cosponsored by the American Institute of Aeronautics and Astronautics and the University of New Mexico

Albuquerque, New Mexico, February 2-6, 2003

National Aeronautics and

Space Administration

Glenn Research Center 


\section{Acknowledgments}

The authors wish to thank Kurt J. Hack, Leon P. Gefert, and Robert D. Falck of the Systems Analysis Branch of NASA Glenn Research Center (GRC) for their assistance and guidance throughout this study. In addition, we wish to thank Shawn Krizan of Analytical Mechanics Associates at NASA Langley Research Center (LaRC) for his CAD design of the $1 / 8^{\text {th }} \mathrm{g}_{\mathrm{E}}$ PCTV developed jointly by LaRC and GRC. We also thank Thomas Packard of Analex Corporation at GRC, for his CAD designs of the Callisto cargo and tanker vehicles also shown in this paper.

This report contains preliminary findings, subject to revision as analysis proceeds.

a

Available from

NASA Center for Aerospace Information 7121 Standard Drive

Hanover, MD 21076
National Technical Information Service 5285 Port Royal Road Springfield, VA 22100 


\title{
High Power MPD Nuclear Electric Propulsion (NEP) for Artificial Gravity HOPE Missions to Callisto
}

\author{
Melissa L. McGuire, Stanley K. Borowski, and Lee M. Mason \\ National Aeronautics and Space Administration \\ Glenn Research Center \\ Cleveland, Ohio 44135 \\ Melissa.L.McGuire@grc.nasa.gov \\ James Gilland \\ Ohio Aerospace Institute \\ Brook Park, Ohio 44142
}

\begin{abstract}
The following paper documents the results of a one-year multi-center NASA study on the prospect of sending humans to Jupiter's moon, Callisto, using an all Nuclear Electric Propulsion (NEP) space transportation system architecture with magnetoplasmadynamic (MPD) thrusters. The fission reactor system utilizes high temperature uranium dioxide $\left(\mathrm{UO}_{2}\right)$ in tungsten $(\mathrm{W})$ metal matrix "cermet" fuel and electricity is generated using advanced dynamic Brayton power conversion technology. The mission timeframe assumes on-going human Moon and Mars missions and existing space infrastructure to support launch of cargo and crewed spacecraft to Jupiter in 2041 and 2045, respectively.
\end{abstract}

\section{REVOLUTIONARY AEROSPACE SYSTEMS CONCEPTS (RASC) STUDY GOALS}

The RASC 2002 multi-center study focused on a Human Outer Planet Exploration (HOPE) mission to Callisto, a moon of Jupiter (Troutman, 2003). The main objectives of the HOPE study were (1) to develop revolutionary aerospace systems concepts allowing human exploration missions into the outer solar system and (2) to identify critical technology requirements for realizing of these systems. The results of the HOPE analysis will help guide NASA technology investments in the future that could enable human space missions beyond the Moon and Mars.

\section{Why Callisto?}

The key requirements considered in selecting a worthy exploration destination beyond Mars were (1) the opportunities for conducting interesting science and (2) the availability of in-situ resources to support a human mission. The body chosen for the HOPE study was Callisto, the third largest satellite in the Solar System, and the outermost Galilean moon of Jupiter. Orbiting at a distance of $\sim 1.9$ million kilometers, Callisto is located beyond Jupiter's main radiation belts making its local environment more conducive to human exploration. Callisto is an icy, rocky world with a surface gravity of $\sim 0.127 \mathrm{~g}_{\mathrm{E}}$ and a composition consisting of water-ice and rock in a mixture ratio of 55:45. Besides having significant quantities of water-ice for propellant production, Callisto's heavily cratered and ancient landscape ( $\sim 4$ billion years old) has a relatively low albedo indicating that significant quantities of non-ice materials and asteroid dust may reside on its surface.

\section{MISSION DESCRIPTION}

The HOPE mission consists of sending a crew of six on an expedition to Callisto to establish an outpost and propellant production facility near the Asgard asteroid impact site, a region where the surface crust is potentially rich in water ice. An "all NEP" space transportation system architecture is examined in this paper. It uses a split mission approach involving separate multi-megawatt electric $\left(\mathrm{MW}_{\mathrm{e}}\right)$-class cargo, tanker and piloted vehicles each 
propelled by hydrogen MPD thrusters. Fully automated cargo and tanker vehicles depart first to pre-deploy both orbital and surface assets at Callisto prior to the arrival of the crew onboard the artificial gravity Piloted Callisto Transfer Vehicle (PCTV). The NEP cargo vehicle delivers three different landers for crew ascent / descent, surface habitation and propellant production. The later carries an In-Situ Resource Utilization (ISRU) processing plant and several combination "bulldozer / rover" surface vehicles used to produce liquid oxygen (LOX) and hydrogen $\left(\mathrm{LH}_{2}\right)$ propellant from the Callisto surface ice. This propellant is supplied to the reusable crew ascent / descent vehicle allowing crew rotation / re-supply sortie missions between the orbiting PCTV and the surface habitat every 30 days. A small, mobile nuclear surface Brayton power system, also carried on the ISRU lander, provides $\sim 250 \mathrm{~kW}_{\mathrm{e}}$ to power the ISRU plant and surface habitat, and to recharge the fuel cell power systems of the surface vehicles. The NEP tanker delivers $\mathrm{LH}_{2}$ "return" propellant to Callisto orbit that is subsequently transferred to the PCTV for its trip back to Earth. The tanker remains in orbit where it will function as an orbital propellant depot and refinery once larger scale water extraction and propellant manufacturing operations begin on Callisto. The low thrust trajectory profiles of the cargo and tanker vehicles involve a slow spiral away from the Earth-Moon L1 Lagrange point, a direct heliocentric transfer to Jupiter and then a gradual spiral into Callisto orbit (Melbourne, 1965). Once these vehicles are on station and operating properly, the PCTV departs from L1 using a similar, though higher energy, trajectory to Callisto. After a surface exploration period lasting $\sim 120$ days, the "refueled" PCTV begins its spiral escape from Callisto on a direct return to Earth and an eventual capture back at L1.

\section{Baseline Mission Ground Rules and Technology Assumptions}

The HOPE study established a set of mission and transportation system requirements which included the following: (1) all Callisto-bound spacecraft must depart from the Earth-Moon L1 staging node; (2) the PCTV must transport a crew of six to and from the Jovian moon in less than five years; and (3) it must provide the crew with an artificial gravity ( $g_{a}$ ) environment of $\sim 1 / 8^{\text {th }} g_{E}$ or higher if the in-space transit time exceeds one year; (4) half of the six person crew will explore the surface for a period of 30 days with longer stays requiring crew rotation and re-supply; and (5) the crew ascent / descent, surface habitat and ISRU landers are limited in mass to 40 metric tons $(\mathrm{t} ; 1 \mathrm{t}=1000 \mathrm{~kg})$.

Also assumed in this study is the availability of highly reliable, autonomous systems, "zero boil-off" (ZBO) cryofluid management, routine propellant transfer both in space and on the surface of Callisto, and last but not least, long-life, reusable $\mathrm{LOX} / \mathrm{LH}_{2}$ chemical rocket engines. Maximum hardware commonality among the different vehicles is also utilized wherever possible. Specifically, the cargo and tanker vehicles use a common nuclear power system to provide the electricity for their sustained, low thrust $\left(\sim 24 \mathrm{lb}_{\mathrm{f}}\right.$ at $\left.6.4 \mathrm{MW}_{\mathrm{e}}\right)$, long duration operation. The low thrust trajectory / mission analysis code, VARITOP (Williams, 1994) was used in analyzing this all NEP architecture. Lastly, all the vehicles evaluated utilized advanced "far-term" technology projections (Mason, 2001) for the reactor, power conversion, heat rejection, and power management and distribution (PMAD) systems.

\section{Nuclear Power System Technology Assumptions}

High temperature $(>2000 \mathrm{~K})$, gas-cooled fission reactors provide a continuous and abundant source of thermal energy for the NEP vehicles considered in this study. The reactors are fueled with enriched uranium-235 in the form of uranium dioxide $\left(\mathrm{UO}_{2}\right)$ contained within a tungsten (W) metal matrix "cermet" fuel element with W-alloy cladding. Electrical power is generated using modular, high power, closed cycle, Brayton thermodynamic heat engines. A helium-xenon gas mixture, circulating within a hermetically sealed gas loop in each Brayton engine, picks up thermal energy from the reactor and is then expanded through a single shaft turbine-alternator-compressor unit to generate electricity. Waste heat is rejected to space via radiators. The Brayton engines operate at about $50,000 \mathrm{rpm}$ and the alternator can provide multi-phase, high voltage AC power for the various loads onboard the individual spacecraft. "Far-term" technology performance levels (Mason, 2001) consistent with the 2040 timeframe are featured in the NEP vehicle designs presented here. Examples of these advanced technologies include high temperature material Brayton units with turbine inlet temperatures of $\sim 2000 \mathrm{~K}$, lightweight $\left(\sim 1.5 \mathrm{~kg} / \mathrm{m}^{2}\right)$, "largescale" ( 1500 to $\left.3250 \mathrm{~m}^{2}\right)$ deployable radiators, and high voltage PMAD ( 5000 volts). 


\section{Thruster System Technology Assumptions}

Magnetoplasmadynamic (MPD) thrusters using hydrogen propellant are featured in this "all NEP" space transportation system architecture. Besides operating at a high specific impulse (Isp) value, the MPD also has the added advantages of a high power handling capability and a compact size. In the basic concept of MPD thruster operation, current flows from an outer annular anode to a central cylindrical cathode and through the hydrogen plasma. The radial current (J) and its self-induced azimuthal magnetic field (B) generate an axial (JxB) Lorentz force on the plasma that accelerates it to high exhaust speeds. For this analysis, high power MPD thrusters operating at $2.5 \mathrm{MW}_{\mathrm{e}}$ per thruster and a constant Isp of 8,000 seconds are baselined. The thruster lifetime and efficiency are assumed to be 7500 hours and $64.5 \%$, respectively. The individual thruster mass is estimated at $263 \mathrm{~kg}$ per thruster. The specific mass of the Power Processing Unit (PPU) for each $2.5 \mathrm{MW}_{\mathrm{e}}$ thruster is estimated to be $\sim 1.25 \mathrm{~kg} / \mathrm{kW}$ e with one PPU assumed for each operating thruster.

\section{Tanker Vehicle Characteristics and Mission Specifics}

The NEP tanker vehicle is sized to hold both the "return" propellant requirements of the PCTV, as well as, the propellant needs of the tanker vehicle itself used in transporting its $\mathrm{LH}_{2}$ cargo out to Callisto. Parametric analysis was conducted where the total electrical power level was varied with the outbound "L1-to-Callisto" trip time for a specified payload value. A reactor electrical power level of $\sim 6.4 \mathrm{MW}_{\mathrm{e}}$ was determined to be optimal for the tanker mission placing it and its payload into orbit around Callisto several months before the departure date for the PCTV. As mentioned previously, far-term technology projections were assumed for the various power subsystems. A $15 \%$ contingency multiplier was also included on all masses. The tanker payload consists of four $19 \mathrm{~m}$ long by $7.6 \mathrm{~m}$ diameter tanks each holding $\sim 48.6 \mathrm{t}$ of $\mathrm{LH}_{2}$ propellant. Each tank also has its own active refrigeration system for ZBO propellant storage during the $\sim 3$ year outbound journey to Callisto. The maximum $\mathrm{LH}_{2}$ capacity of the tanker is $\sim 195 \mathrm{t}$ which covers the PCTV return propellant requirements for a variety of propulsion technologies such as the "bimodal" nuclear thermal rocket PCTV option discussed elsewhere (Borowski, 2003). Either a single, high power, highly reliable reactor system or smaller twin reactor systems can be used to supply the $6.4 \mathrm{MW}_{\mathrm{e}}$ of power necessary to maintain the $\sim 24 \mathrm{lb}_{\mathrm{f}}$ of constant thrust supplied by the MPD thrusters. Two right triangle shaped, double-sided radiators provide the $\sim 1500 \mathrm{~m}^{2}$ of necessary heat rejection area. The overall length of the NEP tanker is $\sim 135 \mathrm{~m}$ and its initial mass at L1 is approximately $\sim 244 \mathrm{t}\left(\sim 81 \mathrm{t}\right.$ for the "dry" tanker vehicle structure, $\sim 60 \mathrm{t}$ of $\mathrm{LH}_{2}$ propellant for the MPD thrusters, and $\sim 103 \mathrm{t}$ for the PCTV return propellant and additional propellant processing equipment mass). Figure 1 depicts an isometric view of the tanker vehicle along with its key features and dimensions. Table 1 provides trajectory information and mission mass details.

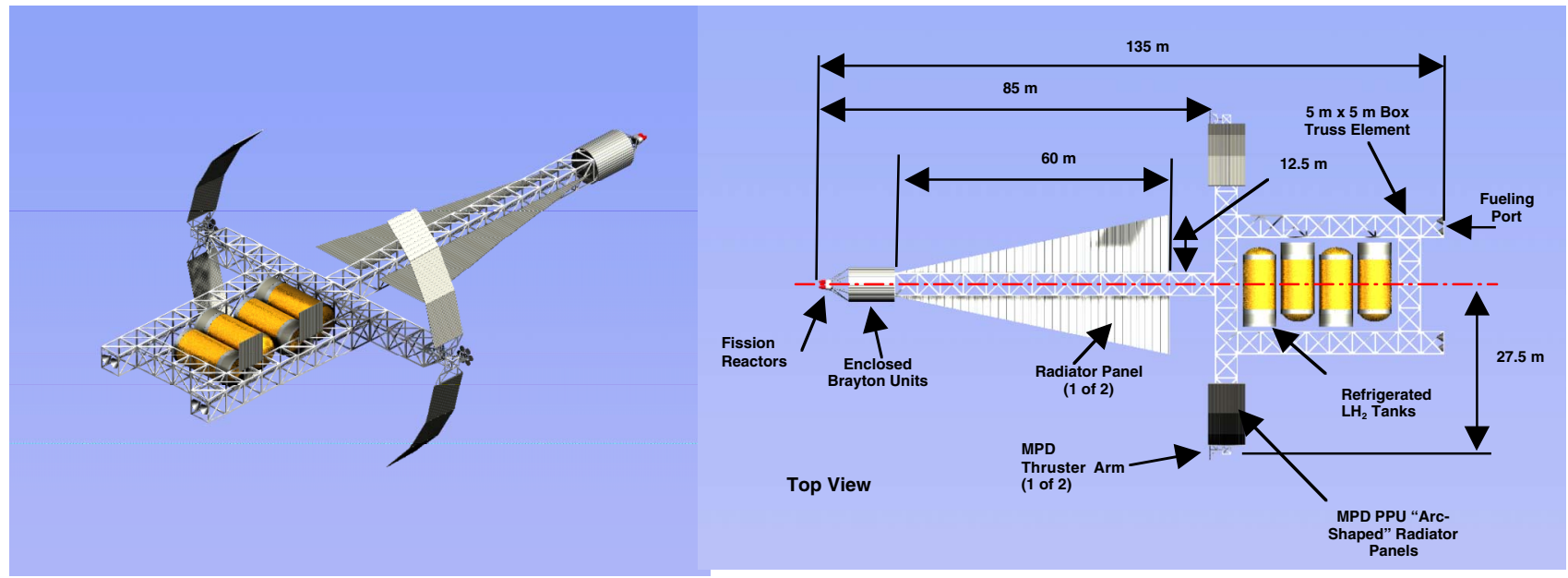

Figure 1. Far-Term NEP Tanker Vehicle Isometric and Representative Features 
TABLE 1. Tanker Vehicle Trajectory and Mission Mass Details

\begin{tabular}{llccc}
\hline Mission Leg & Date & $\begin{array}{c}\text { Trip Time } \\
\text { (days) }\end{array}$ & $\begin{array}{c}\text { Propellant } \\
\text { Mass (t) }\end{array}$ & $\begin{array}{c}\text { Vehicle } \\
\text { Mass (t) }\end{array}$ \\
\hline $\begin{array}{l}\text { Spiral Earth Departure } \\
\text { from L1 }\end{array}$ & September 16, 2041 & 21.2 & 2.5 & $244-241$ \\
$\begin{array}{l}\text { Heliocentric Trip to } \\
\text { Callisto }\end{array}$ & October 7, 2041 & 1012.8 & 46.9 & $241-194$ \\
$\begin{array}{l}\text { Spiral Callisto Capture } \\
\text { Arrival at Callisto }\end{array}$ & July 16, 2044 & 90.3 & 10.5 & $194-183$ \\
& October 14, 2044 & $\begin{array}{c}\text { (total } \sim 3.07 \\
\text { yrs })\end{array}$ & $\begin{array}{c}\text { Total } ~ \\
60\end{array}$ \\
\hline
\end{tabular}

\section{Cargo Vehicle Characteristics and Mission Specifics}

The NEP cargo vehicle's function is to deliver $120 \mathrm{t}$ of spacecraft hardware to Callisto orbit consisting of a reusable crew lander, a surface habitat, and a ISRU propellant processing plant -- each having a mass of $\sim 40 \mathrm{t}$. The cargo vehicle uses the same far-term technology assumptions, 15\% contingency factor and $6.4 \mathrm{MW}_{\mathrm{e}}$ nuclear power system as that used on the tanker vehicle. Besides the $\sim 1500 \mathrm{~m}^{2}$ of primary heat rejection area provided by the two doublesided, triangular-shaped radiators, the cargo and tanker vehicles also have four one-sided, arc-shaped radiator panels (two on each MPD thruster arm) used to dump waste heat from the four MPD thruster power processing units. The curved shape of the PPU radiators helps position them within the reduced radiation conical volume produced by the reactor radiation shields, thereby reducing radiation scatter forward to the payload elements. The $\mathrm{LH}_{2}$ propellant for the cargo vehicle's MPD thrusters is stored in two $19 \mathrm{~m}$ long by $7.6 \mathrm{~m}$ diameter advanced composite material tanks each carrying its own active refrigeration system. The cargo vehicle has an overall length of $\sim 130 \mathrm{~m}$ and its initial mass at L1 is $\sim 242 \mathrm{t}$ ( $\sim 62 \mathrm{t}$ for the "dry" cargo vehicle, $\sim 60 \mathrm{t}$ of $\mathrm{LH}_{2}$ for the MPD thrusters and $\sim 120 \mathrm{t}$ for the crew, habitat and ISRU lander payload elements). An isometric view of the cargo vehicle including its key features and dimensions is shown in Figure 2 while trajectory information and mission mass details are provided in Table 2.

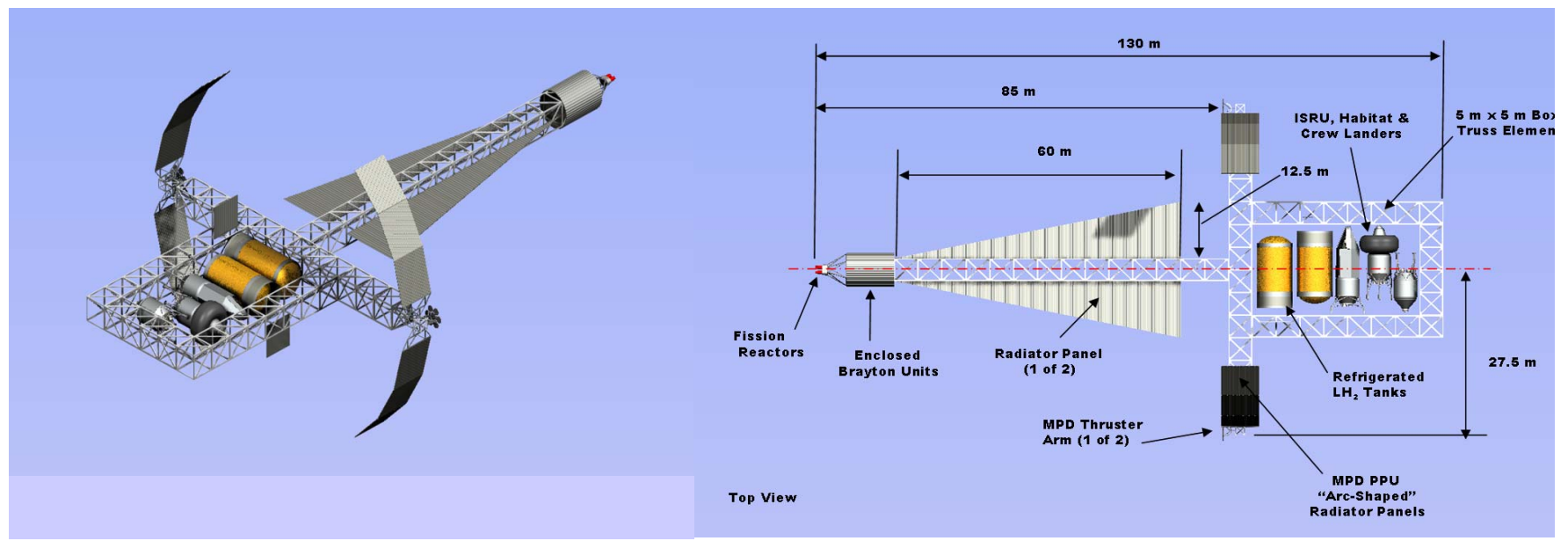

Figure 2. Far-Term NEP Cargo Vehicle Isometric and Representative Features 
TABLE 2. Cargo Vehicle Trajectory and Mission Mass Details

\begin{tabular}{llccc}
\hline Mission Leg & Date & $\begin{array}{c}\text { Trip Time } \\
(\text { days })\end{array}$ & $\begin{array}{c}\text { Propellant } \\
\text { Mass (t) }\end{array}$ & $\begin{array}{c}\text { Vehicle } \\
\text { Mass (t) }\end{array}$ \\
\hline $\begin{array}{l}\text { Spiral Earth Departure } \\
\text { from L1 }\end{array}$ & September 17, 2041 & 21.03 & 2.4 & $242-239$ \\
$\begin{array}{l}\text { Heliocentric Trip to } \\
\text { Callisto }\end{array}$ & October 8, 2041 & 1003 & 46.9 & $239-192$ \\
$\begin{array}{l}\text { Spiral Callisto Capture } \\
\text { Arrival at Callisto }\end{array}$ & July 7, 2044 & 89.28 & 10.4 & $192-182$ \\
& October 4, 2044 & $\begin{array}{c}\text { (total } \sim 3.04 \\
\text { yrs })\end{array}$ & Total $\sim 60$ & 182 \\
\hline
\end{tabular}

\section{PCTV Characteristics and Mission Specifics}

Unlike the "1-way" tanker and cargo vehicles, the PCTV is designed for round trip crew transport. It must therefore carry adequate life support and consumables, and provide an adequate artificial gravity environment to help ensure crew health during the $\sim 4.5$ year long mission to Callisto and back. While in transit, the crew resides inside the inflatable TransHab module, which is located at one end of a dumb-bell shaped structure attached to the front end of the PCTV (see Figure 3). A number of small $\mathrm{LH}_{2}$ propellant tanks are positioned around the TransHab to reduce crew exposure to the deep space radiation environment. Four larger $\mathrm{LH}_{2}$ tanks at the other end of the dumb-bell supply the MPD thrusters with the remaining propellant needed for the mission. These tanks also provide a counterbalance to the shielded TransHab module. As the vehicle rotates about its longitudinal spin axis at $\sim 4 \mathrm{rpm}$, it produces an artificial gravity environment of $\sim 1 / 8^{\text {th }} \mathrm{g}_{\mathrm{E}}$ comparable to that on Callisto. Unfortunately, about halfway back to Earth, there is not enough propellant in the tanks to properly balance the vehicle so the crew is exposed to nearly a year in $0-\mathrm{g}_{\mathrm{E}}$ before arriving back at Earth. Although designed for round trip operations, the PCTV carries only the propellant it needs for the $\sim 2.1$ year outbound trip to Callisto which is $\sim 74$ t. Prior to initiating its spiral capture maneuvers, the PCTV jettisons its "spent" consumables and non-recyclable biowaste to reduce the outbound
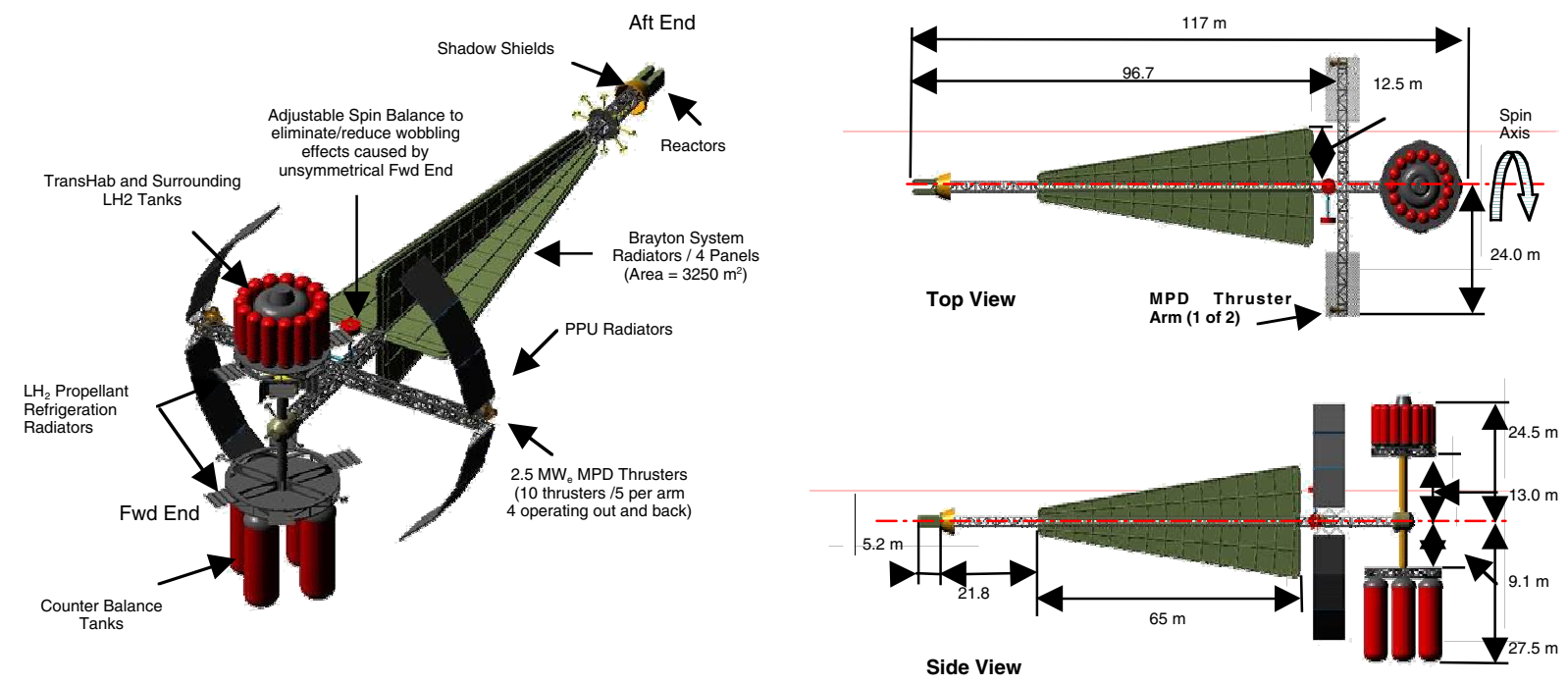

Figure 3. Far-Term NEP / MPD PCTV Isometric and Representative Features 
propellant requirements and the vehicle's total reactor power level. To reduce crew trip time, the PCTV requires a higher electrical power level of $\sim 8.2 \mathrm{MW}_{\mathrm{e}}$. The reactor power system specific mass at this level is $\sim 3.2 \mathrm{~kg} / \mathrm{kW}$. Four right triangle-shaped, double-sided radiator panels $\left(\sim 12.5 \mathrm{~m}\right.$ in height by $\sim 65 \mathrm{~m}$ in length) provide $\sim 3250 \mathrm{~m}^{2}$ of primary heat rejection area which includes a $25 \%$ increase in size due to view factor effects (see Figure 3 ).

During its 120 day stay at Callisto, the PCTV is re-supplied with $\sim 53 \mathrm{t}$ of propellant from the NEP tanker for the $\sim 2.1$ year trip back to Earth. The total mission trip time is approximately 4.5 years. The overall length of the PCTV is $\sim 117 \mathrm{~m}$ and its initial mass at L1 is $\sim 262 \mathrm{t}\left(\sim 109 \mathrm{t}\right.$ for the "dry" PCTV, $\sim 74 \mathrm{t}$ of $\mathrm{LH}_{2}$ for the MPD thrusters and $\sim 79$ t for the TransHab, crew and consumables). Figure 3 depicts an isometric view of the PCTV along with its key features and dimensions. Table 3 provides trajectory information and mission mass details.

TABLE 3. Piloted Vehicle Trajectory and Mission Mass Details

\begin{tabular}{|c|c|c|c|c|}
\hline Piloted Mission Leg & Date & $\begin{array}{l}\text { Trip Time } \\
\text { (days) }\end{array}$ & $\begin{array}{l}\text { Propellant } \\
\text { Mass }(\mathrm{t})\end{array}$ & $\begin{array}{l}\text { Vehicle Mass } \\
\text { (t) }\end{array}$ \\
\hline $\begin{array}{l}\text { Spiral Earth Departure from } \\
\text { L1 }\end{array}$ & December 11,2044 & 13.6 & $\sim 2$ & $262-260$ \\
\hline Heliocentric Trip to Callisto & December 25, 2044 & 703 & 64.5 & $260-196$ \\
\hline Spiral Callisto Capture & November 27, 2046 & 50.2 & 7.5 & $196-188$ \\
\hline Stay time at Callisto & January 17, 2047 & 120 & N/A & $175-228$ \\
\hline Spiral Callisto Departure & May 17, 2047 & 61.1 & 9.1 & $228-219$ \\
\hline Heliocentric Trip to Earth & July 17, 2047 & 689 & 43.2 & $219-176$ \\
\hline Spiral Earth Capture at L1 & June 5, 2049 & 6.5 & $\sim 1$ & $176-175$ \\
\hline $\begin{array}{l}\text { Arrival at Earth (L1 Staging } \\
\text { Node) }\end{array}$ & June 12, 2049 & Total $\sim 4.5 \mathrm{yrs}$ & $\begin{array}{c}\text { Total } \sim 127 \\
(74 \mathrm{OB}, 53 \mathrm{IB})\end{array}$ & $\begin{array}{l}\text { Final Mass } \\
\quad \sim 175\end{array}$ \\
\hline
\end{tabular}

\section{CONCLUSIONS}

A round trip HOPE mission to Callisto in under 5 years appears feasible in the 2045 timeframe using an advanced technology "all NEP" space transportation architecture employing multi-MW $\mathrm{e}_{\mathrm{e}}$-class MPD thrusters. Examples of these advanced technologies include high temperature material Brayton rotating units with turbine inlet temperatures of $\sim 2000 \mathrm{~K}$, lightweight $\left(\sim 1.5 \mathrm{~kg} / \mathrm{m}^{2}\right)$, "large-scale" $\left(\sim 1500\right.$ to $\left.3250 \mathrm{~m}^{2}\right)$ deployable radiators, and high voltage PMAD ( 5000 volts). Gas-cooled fission reactors using high temperature $(>2000 \mathrm{~K}) \mathrm{UO}_{2}$ in tungsten "cermet" fuel, tested during the 1960's, also need to be developed in order to achieve the high performance levels of the Brayton units assumed in this study. Because of Callisto's great distance from Earth ( $>$ times farther away than Mars), a split mission / vehicle approach is recommended for transporting crew and supplies. By using separate cargo, tanker and piloted vehicles, the size and mass of the individual vehicles can be reduced and hardware/system commonality can be maximized. The smaller, multi-vehicle mission approach also eliminates the need for large, complex "Battlestar Galactica"-size spacecraft and exotic propulsion technologies many of which still have major physics feasibility issues that need to be addressed. For the "all NEP" architecture examined here, the masses for the cargo, tanker and piloted vehicles are 242 t, 244 t, and 262 t, respectively, for a three vehicle total at L1 of $\sim 748 \mathrm{t}$. 


\section{REFERENCES}

Borowski, S.K., McGuire, M.L., Mason, L.M., Gilland, J.H., and Packard, T.J., "Bimodal NTR Propulsion for Artificial Gravity HOPE Missions to Callisto", presented at $20^{\text {th }}$ Symposium on Space Nuclear Power and Propulsion, Space Technology and Applications International Forum (STAIF-2003), February 2-6 2003, Albuquerque, New Mexico.

Mason, L.M., "A Comparison of Brayton and Stirling Space Nuclear Power Systems for Power Levels from 1 Kilowatt to 10 Megawatts", NASA/TM-2001-210593.

Melbourne, W.G., and Sauer, C.G., "Performance Comparisons with Pieced Solutions of Planetocentric and Heliocentric Trajectories for Low-Thrust Missions," Supporting Research and Advanced Development, Space Programs Summary 37-36, Vol. IV, pp. 14-19, Jet Propulsion Laboratory, Pasadena, California 1965.

Troutman, P.A., Bethke, K.A., Stillwagen, F.H., Caldwell, D.L., Manvi, R., Strickland, C.V., and Krizan, S.A., "Revolutionary Concepts for Human Outer Planet Exploration (HOPE)," presented at $20^{\text {th }}$ Symposium on Space Nuclear Power and Propulsion, Space Technology and Applications International Forum (STAIF-2003), February 2-6 2003, Albuquerque, New Mexico.

Williams, Steven N., "An Introduction to the Use of VARITOP, A General Purpose Low-Thrust Trajectory Optimization Program,” Jet Propulsion Laboratory, JPL D-11475, 24 January 1994. 


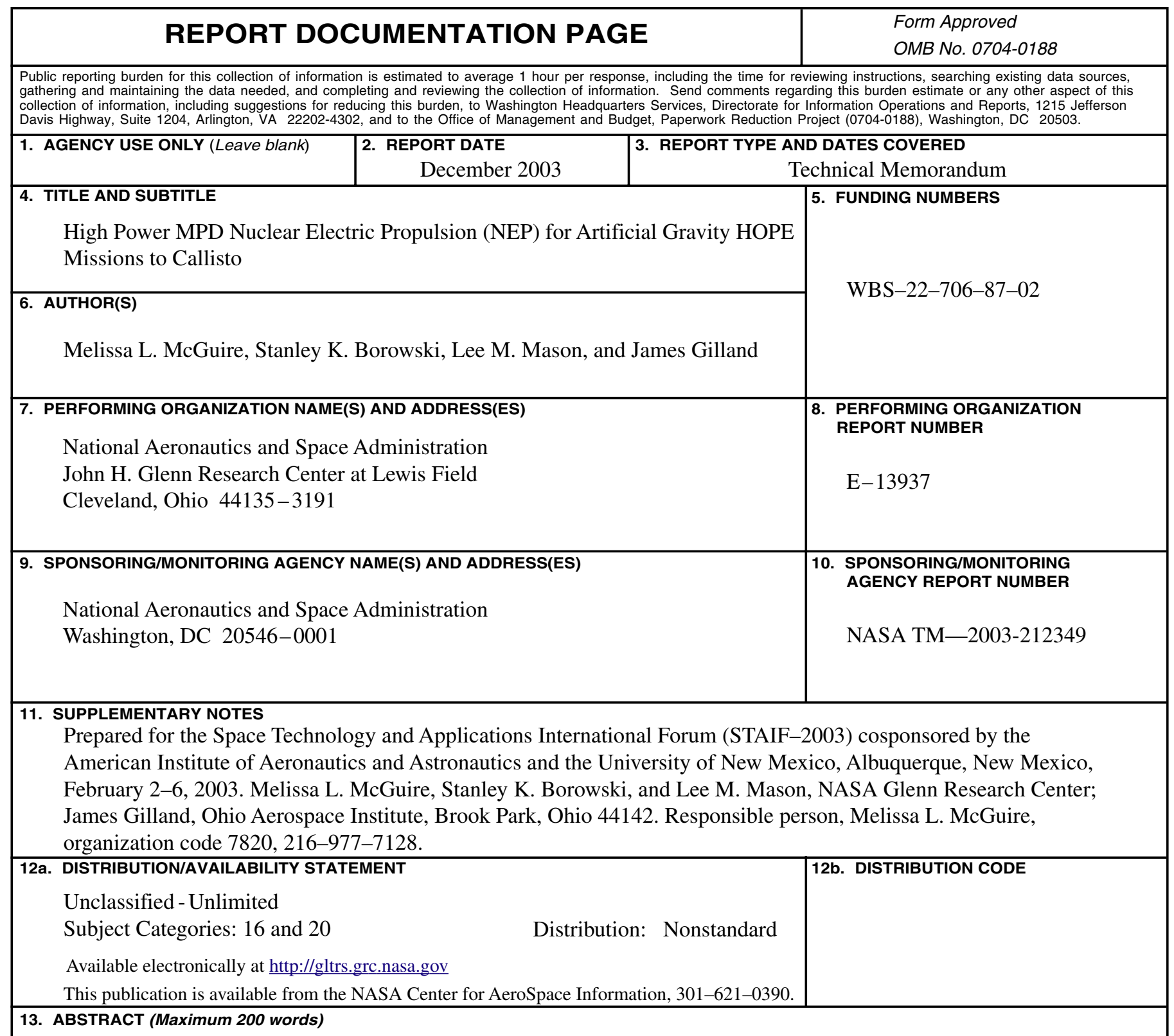

This documents the results of a one-year multi-center NASA study on the prospect of sending humans to Jupiter's moon, Callisto, using an all Nuclear Electric Propulsion (NEP) space transportation system architecture with magnetoplasmadynamic (MPD) thrusters. The fission reactor system utilizes high temperature uranium dioxide $\left(\mathrm{UO}_{2}\right)$ in tungsten (W) metal matrix "cermet" fuel and electricity is generated using advanced dynamic Brayton power conversion technology. The mission timeframe assumes on-going human Moon and Mars missions and existing space infrastructure to support launch of cargo and crewed spacecraft to Jupiter in 2041 and 2045, respectively.

\begin{tabular}{|c|c|c|c|}
\hline \multicolumn{3}{|l|}{ 14. SUBJECT TERMS } & 15. NUMBER OF PAGES \\
\hline \multirow{2}{*}{\multicolumn{3}{|c|}{$\begin{array}{l}\text { Nuclear electric propulsion; Jupiter; Space transportation system; Callisto; Fission; } \\
\text { Magnetoplasmadynamics }\end{array}$}} & \\
\hline & & & 16. PRICE CODE \\
\hline $\begin{array}{l}\text { 17. SECURITY CLASSIFICATION } \\
\text { OF REPORT }\end{array}$ & $\begin{array}{l}\text { 18. SECURITY CLASSIFICATION } \\
\text { OF THIS PAGE }\end{array}$ & $\begin{array}{l}\text { 19. SECURITY CLASSIFICATION } \\
\text { OF ABSTRACT }\end{array}$ & \begin{tabular}{|l} 
20. LIMITATION OF ABSTRACT \\
\end{tabular} \\
\hline Unclassified & Unclassified & Unclassified & \\
\hline
\end{tabular}

